\title{
Rural Social Capital versus European and Global Challenges (About "good" and "bad" Social Capital)
}

\begin{abstract}
This text has two aims - to relate the results of research carried out in IRWiR PAN (Institute for Rural and Agricultural Development Polish Academy of Sciences) on rural social capital and achieve a useful social interpretation of those results referring to the theory of social capital. Social capital is nowadays becoming a very important element in academic and political discourse. It is seen as having the potential for greater efficiency in levelling social differences, improving the opportunities of rural inhabitants. No matter how popular and positive, social capital can be understood in various ways due to its various theoretical sources, it is also possible to point out its negative aspects. This text is an attempt at showing the nuances of how social capital works. The first part presents the basic understanding of the category discussed here. The second part is a presentation of the results of empirical research where interpretation was carried out in the light of earlier outlined concepts.
\end{abstract}

Keywords: social capital, rural development potential, civic society

The challenges nowadays facing Poland's rural areas are twofold. Firstly, they concern certain facts which are considered favourable, on target and assumed in a long-term vision of the development of Europe's rural areas (the changes in social and agrarian structure, food technology, the quality of the labour force, the standard of living of rural inhabitants, the standard of rural infrastructure, etc.). They are expressed by the idea of multifunctional, sustained, neo-endogenous, development of rural revitalisation - in other words the skilful linking of modern and traditional elements, change and 
continuity, agricultural production and the protection of natural resources etc. Secondly, these challenges also concern the readiness of rural communities to effectively take advantage of instruments used by the common agricultural policy in the process of adapting the agriculture of specific member countries to EU standards. These are instruments (and related possibilities) such as direct extra charges, structural rents, funds, foundations and programmes activating rural development etc. They represent considerable Polish rural development capital, far surpassing mere financial support. As we know, making use of the possibilities created by CAP requires not only the ability to raise funds but also an effective way of using and capitalising them.

It would now be difficult to find a study which does not emphasise the enormous significance of social capital in these processes. Whoever uses this concept feels obliged to make clear reservations regarding its application - that it is fashionable, and being fashionable it is not worth much; that it is ambiguous and being ambiguous its interpretations are not particularly transparent; that it is a buzzword, i.e. no concept at all; that, therefore, it would be best not to apply it at all. Nevertheless, literature on the subject is not only growing but the theoretical distinctions between variously defined social capital and theoretical differences have exceptionally important practical consequences.

This text has two aims - to relate results of research carried out in IRWiR PAN on rural social resources and bring about a useful interpretation of these results in the social practice context referring to the social capital theory. The idea behind the research here discussed emerged from clear practical premises. They were times immediately prior to our EU accession. In Poland the SAPARD (Special Accession Programme for Agriculture and Rural Development) programme was being implemented, immediately followed by PAOW (Rural Development Programme). Those programmes set in motion an enormous flow of EU and World Bank funds which were to support rural areas in overcoming their various deficits and problems so as to reduce the gap dividing Poland from EU countries. Bureaucratic regulations imposed by Bruxelles clearly initiated regulations leading to a snowball effect. EU support could successfully be made use of by those who already had considerable capital guaranteeing the effective utilisation of those resources. Who provided such guarantees? Above all those who could already demonstrate some achievements, visible assets. From the perspective of Poland at that time EU policy was blatantly seen as an instrument deepening existing differences.

Such a direction did not seem entirely correct yet there were no academic arguments demonstrating the legitimacy of such thinking. We embarked 
on research which assumed that the state of rural social resources does not necessarily have to be determined by the state of economic, infrastructural or institutional resources, that - perhaps - in areas which were backward economically and in terms of civilisation, the network of social ties was good, as was the willingness to undertake group activities or become engaged in the local community. Research was carried out in six districts. We chose them in such a way that, on the one hand, they represented diverse socio-economic, infrastructural characteristics (a diverse standard of development of the given district), on the other, they presented a wide spectrum of villages portraying Polish uniqueness (peasant, post-state farm, out-of-town, situated in good regions, situated in difficult regions). We researched both the standard and living conditions of rural inhabitants, the functioning of rural education (including local education policies) as well as a wide range of factors which can be included in this comprehensive formula of social resources or human capital. We understood the latter as being (a) a certain readiness of the rural community to undertake local initiatives, engage in solving important issues (such as repairing a bridge, reactions to the closure of the local surgery, (b) the quality of social ties and the level of identity with the local (and wider) community and the presence of local leaders. Human resources included everything we knew or presumed to be important for individuals taking on various challenges (education level, aspirations and life goals, certain mental traits: such as optimism - pessimism, democracy - authoritarianism, feeling well - unwell in the system). It was a question of checking whether the level of human and social capital is a function of the level of environmental development. In other words, did districts with bad (problematic) socioeconomic characteristics have equally bad (poor quality) social and human capital, and good districts have good social and human capital or is there no regularity? In order to better understand rural specificity we outlined a particular point of reference - these were two urban districts where analogical measurements were made ${ }^{1}$.

1 The results of this research were described in two books: Szafraniec, K. (ed.) (2006), Kapitał ludzki i zasoby społeczne wsi. Ludzie - społeczność lokalna - edukacja [Human Capital and Rural Social Resources. People - The Local Community - Education], Warszawa: IRWiR PAN and Szafraniec, K. (ed.) (2006), Jednostkowe i społeczne zasoby wsi, [Individual and Social Rural Resources], Warszawa: IRWiR PAN. 


\section{Definitions of Social Capital}

The concept of social capital is accepted and widely used in both public and academic discourse. The basic connotations and usage link social capital to cohesion and cooperation within a community. Social capital refers to institutions, unions and norms which shape the quality and quantity of group interactions. [...] Social capital is not only the entirety of institutions which uphold the community - it is the glue which holds them together (World Bank 1999; Smith 2001). That 'holding together' is the pivot of analyses with social capital in the background. Social capital consists of a collection of active links between people: trust, mutual understanding, shared values and behavioural patterns which join members into human nets and communities making cooperation possible (Cophen and Prusak 2001, p. 4).

This commonly used concept originates from two different theoretical traditions. The first is the concept of Pierre Bourdieu's cultural structuralism, the second is James Coleman's theory of rational choice and social exchange. The concept of the latter became the basis for the theory of social capital which conquered world fame by being popularised by Robert D. Putnam. In analyses with social capital as a basic explanatory category two traditions come together, that is why the way they define social capital must briefly be specified.

For Bourdieu social capital is a collection of current or potential resources associated with owning a permanent network of more or less institutionalised mutual relations and recognitions - or in other words, with membership in the group - which provide each member with support in the form of mutually held social capital, an authentication which allows for credit in a wide understanding of this word. These relations can only exist in the practical sense, in material and/ or symbolic exchanges which enable them to be maintained. They can also be socially sanctioned (institutionalised) and guaranteed by the use of a common name (surname, membership of a social class, tribe, school, political party etc.) and through a whole range of institutionalised activities planned in order to form and inform those who are subjected to them (Bourdieu 2004, p. 210). Capital understood in this way is the property of individuals who in rivalry with others for social status, prestige and power in different, symbolically diversely organised fields of activity, make use of this resource. It becomes part of the heedless strategies realised automatically during social activity. Social, cultural and economic capital are part of the unconscious economics of social activity. 
In simpler terms, social capital means people to whom we can turn to, contacts we can refer to, people from whom we can learn cultural competences, acquire knowledge, borrow money. The quality of social capital, its quantity and market value depend on the "quality" of the people creating social affiliation networks. As Stephen Ball points out (2003) the social capital of the middle class is far richer and more pragmatically useful than the social capital of members of the working class. This is determined by the level of cultural capital and access to economic and cultural resources of those surrounding the particular individual.

For James Coleman social capital is a public rather than an individual commodity. It is a feature of the social group which being equipped with a flow of information, common values and effective sanctions creates conditions in which individuals function (Coleman 1988). The level of social capital, often identified by the level of trust is higher in well structured groups, clear, widely divided norms and values. This leads to the readiness of setting up associations and becoming engaged in group activity in order to provide prosperity to the members of the group. As Alejandro Portes comments vividly "social capital created in closely knit communities is useful for parents, teachers or the police in order to maintain discipline and create solidarity between those over whom they have control" (Portes 1998, p. 10). For Coleman small compact communities are a better base for building human capital than large heterogeneous groups. That happens due to structural closure which leads to various aspects of social functioning of individuals intersecting with one another, reinforcing the controlling power of the community which guards values and limits potentially negative behaviour which differs from the generally accepted principles. In a nutshell, in small compact communities the social activities of individuals constantly intersect with one another (at work, between neighbours, in the shop, at church) reinforcing the feeling of community and also the feeling of social control. This base gives rise to trust which is the effect of belief in the predictability of behaviour of other members of the group. Predictability resulting from sharing common values and the inevitability of sanctions threatening the breakdown of norms.

Coleman's deliberations were developed in the work of Robert D. Putnam (2000), who extends his analysis by distinguishing two types of social capital: bonding and bridging. This can be analysed in the dimension of tensions between bonding and excluding as well as bridging and including. Building social capital can lead to strengthening the links between the members of a community creating an exclusive group of people who work together for the 
common good. On the other hand, it can lead to creating social capital allowing for bridging, acquiring access to new resources. Bonding social capital brings the community together, bridging opens it up to other environments (different cultural groups, institutions and social segments). These two dimensions do not exclude one another but can assume diverse characteristics. We can thus come across communities with a high bonding capital and low bridging capital and vice versa. From the point of view of socio-economic development a harmony between the values in both dimensions would be ideal, neither being extreme - a relatively coherent group, open to diverse cultural patterns and social structures.

Both traditions (Bourdieu, Coleman and Putnam) are unanimous in their perception of the individual in the social environment, its group history, resources enabling its activities, creating but also restricting possibilities if they assume specific characteristics. In most research social capital is treated as something naturally good. The higher the level of social capital, the better the functioning of local structures, better educational achievement, less social pathology, the greater the readiness to undertake challenges which come with varying circumstances. Investment in social capital are one of the most publicised objectives of current social and economic policy. This can even be described as the political ideology of social capital which by glorifying the community presents it as an alternative to the lonely individual in late modernism. It should, however, be remembered that the characteristics of concrete groups as regards social capital can be either catalytic or destructive of social change. When observing the social conditions of economic development in the Polish countryside nowadays attention should be paid to its social resources. Is the fact of backwardness in terms of civilisation connected with the low level of social capital? Perhaps other characteristics than merely the size of that capital are more important? Further analysis is a tentative attempt at answering these questions.

\section{Rural Social Resources}

Analysing the rural social resources we considered various references from the most immediate circle, referring to matters of the local village or district to those concerning the countryside as a whole and finally the widest circle, involving matters of the entire country. Four categories of capital were distinguished. The first was social trust capital, measured by questions 
regarding trust in people, institutions, political parties. The second category was social activity capital, showing the readiness to get engaged in actions aimed at helping others and/or the readiness to intervene when important matters of the local community are threatened. The third category of capital concerns civic attitudes. These include the sense of having an influence on matters concerning one's own village, commune, district, country as well as participation in local elections and the EU referendum. The fourth category is innovative capital which includes rural inhabitants' attitudes towards changes occurring in the Polish countryside and in Poland after $1989^{2}$.

Table 1. Social trust capital versus type of district - urban and rural group $(\mathrm{N}=1117$, data in $\%)$

\begin{tabular}{|l|c|c|c|c|c|}
\hline $\begin{array}{c}\text { Type of district } \\
\text { STC - level }\end{array}$ & $\begin{array}{c}\text { Good } \\
\text { suburban } \\
\text { districts }\end{array}$ & $\begin{array}{c}\text { Average } \\
\text { peasant } \\
\text { district }\end{array}$ & $\begin{array}{c}\text { Feeble } \\
\text { peasant } \\
\text { district }\end{array}$ & $\begin{array}{c}\text { Rural } \\
\text { districts in } \\
\text { general }\end{array}$ & $\begin{array}{c}\text { Urban } \\
\text { districts }\end{array}$ \\
\hline Low & 37.1 & 27.4 & 39.8 & 35.8 & 74.0 \\
\hline Average & 44.4 & 66.1 & 45.7 & 47.9 & 21.0 \\
\hline High & 18.5 & 6.5 & 14.5 & 16.3 & 5.0 \\
\hline Altogether & 100.0 & 100.0 & 100.0 & 100.0 & 100.0 \\
\hline
\end{tabular}

Source: Research project: Human Capital and Social Resources of Countryside

Social trust capital including the declared level of confidence in people, institutions and political groups, generally reaches an average position in the countryside which means that confidence towards partners in social interaction is often selective. As a rule rural inhabitants trust people within their immediate circle, they do not trust 'outsiders', particularly those representing public institutions, political groups or state institutions. Differences within rural districts are not all that large and the fact of living in the countryside is far more significant than the features of social status. Representatives of the intelligentsia are relatively most open socially, rural entrepreneurs being the most distrustful. Meanwhile, according to table 1, the level of social trust in the countryside is far better than in town (see table 1).

2 A code was assumed according to which every type of social capital is built on the basis of several variables which are evaluated. These values are: low, average and high. Details of evaluation procedure - see: Szafraniec, K. (2006), Zasoby jednostkowe z perspektywy pytania o bezradność i roszczeniowość polskiej wsi [Individual Resources from the Perspective of Questions about Helplessness and Demands of the Polish Countryside], in: K. Szafraniec (ed.), Kapitał ludzki... [Human Capital...], Warszawa: IRWiR PAN. 
The situation presented in the second category is totally different - social activity capital (table 2) where an evaluation is made of opinions about the sense of group activities, the personal readiness of getting engaged in activities concerning other people, including the local community. We presented the interviewees with two situations which could take place in any village or urban estate.

The wooden bridge over a stream is damaged. It is a convenient and frequently used link with the neighbouring village which has shops, railway and bus stations. The bridge is in need of repair - the wood is decaying, there are holes in the planks, it is becoming dangerous.

In your opinion, who should do something about this? And further: Would you personally take the initiative to do something about this?

The local surgery is very good but the National Health Service intends closing it down. The surgery can be saved but that would require considerable engagement. What would you do in this matter?

- I would get personally involved and do several things

- I would not know what to do personally but if asked would gladly join others in helping

- I would not get involved and would use private medical care or go elsewhere

- I would feel abandoned, no longer having the right to anything, useless

- I would not do anything - it is not up to me to think about such matters

- I do not have an opinion

Thehigh assessment of social cooperation and readiness to takeindependent social initiatives was very highly evaluated. The moderate involvement and ambivalence in getting involved in group activities was qualified as an average level of social capital. The feeling of senselessness in getting involved in matters concerning everybody and the passive, wait-and-see, demanding, indifferent way of reacting to problems of the local community were seen as low-income indicators.

The convictions and reactions of interviewees in this area gave a totally different picture to the previous one, showing an enormous gap between the sphere of social trust (particularly with regard to 'others') and a willingness to get engaged in local community issues - in favour of the latter (table 2).

Rural inhabitants in particular see the point of getting involved in community matters, especially when they concern problems within their own 
Table 2. Capital of social activity versus type of interviewed district - rural and urban group ( $\mathrm{N}=1117$; data in $\%)$

\begin{tabular}{|l|c|c|c|c|c|}
\hline $\begin{array}{c}\text { Type of district } \\
\text { CSA - level }\end{array}$ & $\begin{array}{c}\text { Good } \\
\text { suburban } \\
\text { districts }\end{array}$ & $\begin{array}{c}\text { Average } \\
\text { peasant } \\
\text { districts }\end{array}$ & $\begin{array}{c}\text { Feeble } \\
\text { peasant } \\
\text { districts }\end{array}$ & $\begin{array}{c}\text { Peasant } \\
\text { Districts in } \\
\text { general }\end{array}$ & $\begin{array}{c}\text { Urban } \\
\text { districts }\end{array}$ \\
\hline Low & 7.1 & 1.2 & 6.2 & 8.8 & 17.0 \\
\hline Average & 49.1 & 32.7 & 43.7 & 43.1 & 64.0 \\
\hline High & 43.8 & 66.1 & 50.1 & 48.2 & 19.0 \\
\hline Altogether & 100.0 & 100.0 & 100.0 & 100.0 & 100.0 \\
\hline
\end{tabular}

Source: Research project: Human Capital and Social Resources of Countryside

environment. The most typical reaction - both in the case of the damaged bridge and in that of planning to get rid of the surgery - is one of taking initiative or getting involved in activities undertaken by others - without expecting this to be done by the authorities or other specialised institutions. In similar circumstances, inhabitants of urban districts are more likely to rely on the initiative and help of institutions and consider that it is not up to them to do anything for themselves.

It is interesting that the readiness to get involved in activities aimed at benefiting the local community is particularly noticeable in peasant districts with moderate and unfavourable development characteristics. This can be explained by the relatively good level of social ties in local rural communities. It also seems that there is something more there. No doubt judging social engagement highly has its roots in the peasant tradition of mutual help. Historical experiences are also significant, consolidating the conviction of rural inhabitants about their marginalisation and loneliness which means that in difficult situations they can rely on one another. Something which cannot be overrated is the role of local rural community leaders who coming from that community acquire the trust as being 'one of $\mathrm{us}^{3}$.

Let us now analyse the type of social capital which refers to the civic attitudes of rural inhabitants (Table 3).

${ }^{3}$ See: Fedyszak-Radziejowska,B.(2006), Kapitałspołeczny wsi-wposzukiwaniu utraconego zaufania [Social Rural Capital - Searching Lost Trust], in: K. Szafraniec (ed.), Kapitat ludzki... [Human Capital], Warszawa: IRWiR PAN. 
Table 3. Civic capital in the researched Rural Districts ${ }^{4}(\mathrm{~N}=1017$, data in\%)

\begin{tabular}{|l|c|c|c|c|}
\hline $\begin{array}{c}\text { Type of district } \\
\text { CC }- \text { level }\end{array}$ & $\begin{array}{c}\text { Suburban } \\
\text { districts }\end{array}$ & $\begin{array}{c}\text { Average peasant } \\
\text { district }\end{array}$ & $\begin{array}{c}\text { Feeble peasant } \\
\text { districts }\end{array}$ & Altogether \\
\hline Low & 50.6 & 27.4 & 35.7 & 39.1 \\
\hline Average & 37.1 & 48.8 & 46.0 & 42.0 \\
\hline High & 12.4 & 23.8 & 18.3 & 18.9 \\
\hline Altogether & 100.0 & 100.0 & 100.0 & 100.0 \\
\hline
\end{tabular}

Source: Research project: Human Capital and Social Resources of Countryside

We made statements about it on the basis of some questions - sounding out the sense of influence (on matters concerning the village, district, county, country) and electoral activity. The wide sense of influence, covering the whole country and statements on electoral participation (local, parliamentary and EU referendum) provided a basis for a relatively high evaluation of civic capital. Attitudes pointing to the shorter radius of civic participation were qualified among the average evaluations whereas the lack of a sense of influence and declarations of non-participation in elections resulted in low evaluations.

According to data in Table 3 high quality civic capital in rural districts is very rare. The low level, in other words political passivity and alienation is a phenomenon appearing twice as often. In some districts that capital is even weaker. That is the case in districts with a predominance of professionally passive or working class population (suburban districts) and backward districts where hopelessness translates into political passivity and alienation. Civic capital there seems to remain directly linked to social trust capital. Where that trust is low and narrowed down to the most immediate circle, there is no civic effect. The case of small fatherlands is an exception. Civic capital in the broader sense is non-existent particularly where the lack of a sense of social safety is combined with the lack of prospects (villages in backward regions with a domination of traditional peasant economy).

An important element of social capital which largely determines the way in which it will be put to use is the relationship towards changes taking place in the countryside in its broader social surroundings. It can easily be imagined that the readiness to become engaged in favour of the common good - most noticeable in local identification in the countryside - can give diverse results. It can show exclusive tendencies, ossifying the village and isolating it from

${ }^{4}$ Due to the specificity of these questions, placing civic attitudes within the context of specific rural problems, we do not have comparable materials referring to urban districts. 
external influence. It can show assimilative tendencies, ignoring the rural specificity. It can also mean the readiness to open up in the name of defending specifically rural values. Much depends on the kind of reality and direction of change is shared by the majority. A lot also depends on local leaders who can convert social engagement into various types of activity.

So what is the attitude of rural inhabitants to change? Do they accept the general line of reforms implemented and announced in the country? We asked for an evaluation of various situations and changes both in the context of the interviewee's own village, the countryside, as well as Polish society as a whole. We called all these attitudes and evaluations connected with the direction of changes taking place innovative capital, here meaning the level of openness towards those changes. As in the case of other kinds of social capital, so here also we used a gradation distinguishing the low level of innovative capital (manifesting reluctance to change, considering it as a threat), an average level (ambivalent, heterogeneous approach) and a high level (manifesting a rationally positive approach towards change, treating it in categories of opportunity and challenge).

From the data collected during the research it emerges that there are still very few enthusiasts of the system transformation and changes resulting from that process in the countryside (7.9\%). There are $6 \frac{1 / 2}{2}$ times as many who are definitely unenthusiastic (Table 4). The majority (over half) are ambivalent, which should be considered as a rational approach, not determining unwillingness or xenophobia. It is hard to be enthusiastic about something which raises so much anxiety.

Table 4. Innovative Potential of Rural and Urban Districts ( $\mathrm{N}=1117$, data in\%)

\begin{tabular}{|l|c|c|c|c|c|}
\hline $\begin{array}{c}\text { Type of district } \\
\text { IP - level }\end{array}$ & $\begin{array}{c}\text { Suburban } \\
\text { districts }\end{array}$ & $\begin{array}{c}\text { Average } \\
\text { peasant } \\
\text { districts }\end{array}$ & $\begin{array}{c}\text { Feeble } \\
\text { peasant } \\
\text { districts }\end{array}$ & $\begin{array}{c}\text { Rural } \\
\text { districts } \\
\text { altogether }\end{array}$ & $\begin{array}{c}\text { Urban } \\
\text { districts }\end{array}$ \\
\hline Low & 43.5 & 45.8 & 42.8 & 40.1 & 31.0 \\
\hline Average & 48.8 & 51.8 & 53.1 & 52.0 & 69.0 \\
\hline Relatively high & 7.6 & 2.4 & 4.1 & 7.9 & - \\
\hline Altogether & 100.0 & 100.0 & 100.0 & 100.0 & 100.0 \\
\hline
\end{tabular}

Source: Research project: Human Capital and Social Resources of Countryside

Farmers, minor entrepreneurs and unemployed people are the greatest sceptics. In their opinion the prospect of Poland being in the EU raises concern and a sense of threat. Groups with certain assets (education, qualifications, 
machinery) - wealthier entrepreneurs, specialists, youngsters in education have a different attitude towards Poland's openness to change. For them the prospect of rationalising many solutions in the countryside and agriculture, Poland's presence in the EU appear as hope for improving living conditions and increasing opportunities. Young people are decidedly in favour of openness towards change. Farmers - the greatest opponents of Poland's entry into the EU - mellowed in their assessment as soon as they noticed that EU resources are the only ones to be used in introducing change in the countryside and supporting local initiatives ${ }^{5}$.

Considering all these elements of social capital as a whole gives a picture of a certain style of presence in the public sphere. Knowing this gives an idea about the kind of support to be expected in programmes activating local rural milieus or various types of implementation.

Table 5. The Style of Presence in the Public Sphere (social resources) and the type of district $(\mathrm{N}=1117$; data in $\%)$

\begin{tabular}{|l|c|c|c|c|c|}
\hline $\begin{array}{c}\text { Type of district } \\
\text { Way of } \\
\text { functioning }\end{array}$ & $\begin{array}{c}\text { Suburban } \\
\text { districts }\end{array}$ & $\begin{array}{c}\text { Average } \\
\text { peasant } \\
\text { districts }\end{array}$ & $\begin{array}{c}\text { Feeble } \\
\text { peasant } \\
\text { districts }\end{array}$ & $\begin{array}{c}\text { Rural } \\
\text { districts } \\
\text { altogether }\end{array}$ & $\begin{array}{c}\text { Urban } \\
\text { districts }\end{array}$ \\
\hline $\begin{array}{l}\text { Distrustful, } \\
\text { passive }\end{array}$ & 25.6 & 9.5 & 18.3 & 19.4 & 24.0 \\
\hline Ambivalent & 55.0 & 63.1 & 57.2 & 54.9 & 69.0 \\
\hline Open, involved & 19.4 & 27.4 & 24.5 & 25.8 & 7.0 \\
\hline Altogether & 100.0 & 100.0 & 100.0 & 100.0 & 100.0 \\
\hline
\end{tabular}

Source: Research project: Human Capital and Social Resources of Countryside

Data in Table 5 reveal the dominance (55\%) of the ambivalent type - who is careful in evaluating system changes, distrustful towards the non-rural environment, sensitive on matters of the immediate community and willing to get engaged in its favour, on condition that others within the immediate group will be its initiators. This creates a bundle of features which fits into the picture of the 'average' Polish citizen: not too convinced about his/her own influence on the functioning of state institutions or devices but not refusing him/herself the right to at least decide about the course of choices; not rejecting the idea of

${ }^{5}$ Jerzy Głuszyński, 'Opinie mieszkańców wsi i rolników na temat integracji, przed i po wejściu Polski do Unii Europejskiej' ['The Views of Rural Inhabitants and Farmers on Integration, before and after Poland's Entry into the EU'], Wieś i rolnictwo 2005 (special issue). 
social solidarity but also more willingly making the most of privileges of the citizen who has state offices and institutions at his/her disposal.

Second numerically came the open, involved type (26\%) who describes two rather different styles of functioning. The first is an example of the ethical, active citizen, the second is an example of the ethical dreamer. They both have attitudes of social engagement, the conviction about the correctness of undertaking mutual activities for the general good and readiness to carry out certain duties. In both cases lies the awareness of being able to influence matters which are far wider than those affecting the immediate surroundings and considerable political criticism. We noticed declarations of high electoral activity in both cases. What essentially distinguishes the ethical, active citizen from the ethical dreamer is the way of treating changes taking place in Poland and expectations connected with Poland's presence in the EU. The former strongly believes in the sense and necessity of further change because s/he sees them as an essential condition of his/her own life activity whereas the latter accepts changes, hoping that they will change - through the wave of a magic wand - his/her life situation and guarantee a safer future.

The ethical, active citizen type is one who appears among rural elites, but not only. $S /$ he is partly represented by members of the rural intelligentsia, more expansive entrepreneurs, young adults in education. The ethical dreamer type is typical in districts with unfavourable socio-economic characteristics.

Attitudes which are distrustful, passive, indifferent of people who neither have the need to get involved in the matters of others nor show the readiness to social cooperation (believing that solving 'certain' problems belongs to others offices, institutions) are the least numerous in the countryside, even less so than in the urban environment. Differences between villages in agricultural (and peasant) regions and suburban villages, which are closer to the town (they have many distrustful and passive people), although - on the other hand they have far more open and involved people than in urban districts.

Can the principles observed here be of any practical value? They probably can if we take a look at the last two columns in the table - presenting data concerning rural and urban districts. We can easily notice that the stereotype talking about the degeneration of social capital in the countryside does not find confirmation in this research. In addition, the essential syndrome of factors making up social capital is clearly better in districts which are backward in terms of civilisation. Although the data defends itself in the light of existing knowledge about traditional, culturally homogeneous local communities, it is nevertheless surprising in a sense and difficult to interpret. Mainly because 
it inspires easy optimism - poor, backward rural communities have at their disposal powerful social capital which nobody would have expected of them and which is such a very rare and sought after value. Should we, therefore, really be so happy and why?

Lets return to the distinction made earlier between bonding and bridging capital. The former can be described in dimensions of strengthening bonds and excluding, the latter in building bridges and including. Building social capital may lead to reinforcing bonds within the community, it can also lead to social capital, allowing the building of bridges, i.e. opening itself to new types of bonds, new values, new - different, culturally 'alien' resources which not only indicate assimilation to the dominant culture and requirements of global society (they join up with the wider community) but also provide new resources which can help solve local problems and carry out community interests.

According to Putnam bonding capital is a set of attributes depicting a specific system of reciprocity and solidarity within the group, institution, local community. Bridging capital is a set of attributes depicting the readiness of people (communities) to open themselves up to what is beyond and above them, a certain readiness to enlarge their own resources by those which can be acquired by building bridges. Bridging capital may generate further identification extending beyond the local system, whereas bonding social capital supports narrow identities, closing itself from the possibility of getting enriched with otherness.

These terminological distinctions, which are not all that subtle, lead us to discovering that social capital does not only have one, bright side, that there is both 'good' and 'bad' social capital. And no matter how many suspicions this type of bond gives rise to, which R. Putnam described as social bonding capital, it cannot be considered a priori that bridging capital is beyond suspicion. A. Portes mentions four 'dark' sides of strong social capital. The first is connected with the danger of excluding people from outside one's own group (community) whenever others seem to be a threat to the cohesion and identity of the group or reduce potential access to socially valued assets. That brings about a tendency to maintain the sense of community for its members only. The second danger of powerful social capital is linked with the risk of restricting initiative and ossification of the community if social capital is to be built on the negation of novelty, within 'traditional' rules of group life. Thirdly, powerful social capital (powerful bonds and group norms) does not allow much space for individualism, which is in itself not unproblematic, 
nevertheless it does also have significant positive sides. Fourthly, high social capital creates mechanisms enabling the maintenance of social disproportions which hinder the overcoming of deeper tensions in the system - it allows for the survival of groups which concentrate on cultures opposing the dominant culture creating a bottleneck to change which are reached by neither persuasion strategies, social engineering nor programmes stimulating initiative (e.g. self-reproductive poverty culture).

If we therefore, talk about social capital it is worth being aware of the fact that it does indeed not only have one, the brightest and only positive side. The research referred to here confirms this intuition although it has come to a standstill at the point where the problem is only beginning. Another significant observation made in this research (thanks to Barbara FedyszakRadziejowska) is pointing out the very important role of local leaders in the process of building social capital. Referring this observation to Putnam and Portes's remarks we can say that much depends on local community leaders. It particularly depends on whether social capital will be built with the idea of social inclusion or exclusion, whether it will refer to the bonding or the bridging type of links, whether it will be competent to increase internal rural resources so as to increase the willingness of local communities to face new challenges or to maintain group individuality and use its potential to solve its own local problems. In the hands of the leaders and the whole LEADER programme lies not only the issue of activating local resources and initiatives but also the issue of responsibility for their appropriate direction and consequences which are of more long-term significance.

\section{References}

Ball, S., Class Strategies and the Educational Market. The Middle Classes and Social Advantage, London 2003: Routledge Falmer.

Bourdieu, P., Distinction. A Social Critique of the Judgment of Taste, London 1994: Routledge.

Bourdieu, P., The Forms of Capital, in: S. Ball (ed.) The Routledge Falmer Reader in Sociology of Education, London 2004: Routledge Falmer, pp. 15-29.

Coleman, J., 'The Role of Social Capital in the Creation of Human Capital', American Journal of Sociology, vol. 94, 1988, pp. 95-120.

Cohen, D., Prusak L. (), In Good Company. How Social Capital Makes Organizations Work, Boston Ma 2001: Harvard Business School Press. 
Czapiński, J., Kapitał społeczny [Social Capital], in: J. Czapiński, T. Panek (eds.), Diagnoza Społeczna 2005, Warunki i jakość życia Polaków [Social Diagnosis 2005, Conditions and Quality of Life of the Poles], 2005, pp. 204-214; available on: http://www.diagnoza.com/.

Fedyszak-Radziejowska, B., Kapitat społeczny wsi - w poszukiwaniu utraconego zaufania [Rural Social Capital - in Search of Lost Trust], in: K. Szafraniec (ed.), Kapitat ludzki i zasoby społeczne wsi. Ludzie - społeczność lokalna - edukacja, [Human Capital and Rural Social Resources. People - The Local Community - Education], Warszawa 2006: IRWiR PAN, pp. 71-120.

Fine, B., Social Capital vs. Social Theory, Political Economy and Social Science at the Turn of the Millennium, London 2005: Routledge.

Gaggio, D. (), 'Do Social Historians Need Social Capital?', Social History, vol. 29, no 4, 2004, pp. 499-513.

Portes, A. (), Social Capital: its Origins and Applications in Modern Sociology, Annual Review of Sociology, vol.24, 1998, pp. 1-24.

Putnam, R.D., Bowling Alone. The Collapse and Revival of American Community, New York 2000: Simon and Schuster Paperbacks.

Smith, M. K., Social Capital, The Encyclopedia of Informal Education, 2001, www.infed.org/biblio/social_capital.htm. 